\title{
A Heparin-Coated Circuit Reduces Complement Activation and the Release of Leukocyte Inflammatory Mediators During Extracorporeal Circulation in a Rabbit
}

\author{
Frans B. Plötz, *Willem van Oeveren, †Karl A. Hultquist, †Cathie Miller, \\ †Robert H. Bartlett, and *Charles R.H. Wildevuur \\ Department of Pediatrics, Neonatology, University Hospital; *Research Division, Cardio-Pulmonary Surgery, \\ University Hospital, Groningen. The Netherlands; and †Department of Surgery, University of Michigan Hospitals, \\ Ann Arbor, Michigan, U.S.A.
}

\begin{abstract}
Heparin coating modifies complement activation during extracorporeal circulation much more effectively than systemically administered heparin. This rabbit study was undertaken to address possible mechanisms responsible for this difference. We evaluated the effect of heparin coating on complement activation and subsequently the release of leukocyte inflammatory mediators during extracorporeal circulation through a simplified circuit. We found in the heparin-coated group a significantly reduced complement hemolytic activity $\left(\mathrm{CH}_{50}\right)$, remaining higher leukocyte numbers, significantly decreased release of $\beta$-glucuronidase, and most strikingly a complete pre-
\end{abstract}

vention of tumor necrosis factor (TNF) formation. The significantly reduced $\mathrm{CH}_{50}$ activity in the heparin-coated groups indicates the reduction of one or more native classical complement products. This could be explained by the absorption of complement components by the circuit, which results in reduced activity of the complement cascade. We conclude therefore that heparin coating reduces complement activation and consequently reduces the release of leukocyte inflammatory mediators. Key Words: Complement-Leukocytes-Tumor necrosis factorExtracorporeal circulation-Heparin coating-Biocompatibility.
Cardiopulmonary bypass (CPB) is associated with complement activation of both classical and alternative pathways (1-6). Both pathways form C3-convertase, an enzyme able to cleave $\mathrm{C} 3$ and thus generate $\mathrm{C} 3 \mathrm{a}$ and $\mathrm{C} 3 \mathrm{~b}$. The formation of the $\mathrm{C} 3-$ convertase is a critical step in activation of the complement cascade since it augments initial $\mathrm{C} 3$ cleavage and will recruit the effector sequence composed of complement products $\mathrm{C} 5$ to $\mathrm{C} 9$, which will generate the vasoactive, chemotactic, immune regulatory, and cytolytic activity of complement $(7,8)$.

Heparin is known to inhibit the complement system by interfering with $\mathrm{C} 3$-convertase formation in either the classical or alternative pathway in concentrations similar to those needed for anticoagulation

Received January 1992; revised March 1992.

Address correspondence and reprint requests to Prof. $\mathrm{dr}$. C.R.H. Wildevuur, at University Hospital, Research Division, Cardio-Pulmonary Surgery, Oostersingel 59,9713 EZ Groningen, The Netherlands.
(9-11). However, despite heparinization complement activation through both pathways has still been demonstrated in patients undergoing $\mathrm{CPB}$, probably owing to interaction of heparin with other plasma proteins. On the other hand, several studies reported the inhibitory effect of heparin coating on complement activation (12-14). This observation indicates that the inhibitory action of heparin on complement activation is much more effective by coating the total inner surface of the extracorporeal circuit with heparin.

However, it remains unclear why heparin coating is much more effective than systemically administered heparin in modifying complement activation. We hypothesize that heparin coating may promote the absorption of native complement products by the extracorporeal circuit, thus preventing the generation of complement split products. This rabbit study was undertaken to evaluate the effect of heparin coating on complement activation and subse- 
quently the release of leukocyte inflammatory mediators during extracorporeal circulation through a simplified circuit.

\section{MATERIALS AND METHODS}

\section{Animals}

Fasted New Zealand white rabbits were anesthetized with intramuscular injections of xylazine (20 $\mathrm{mg} / \mathrm{kg})$ and ketamine $(25 \mathrm{mg} / \mathrm{kg})$. Additional anesthesia was maintained with ketamine. The rabbits were secured in a supine position and prepared for surgery. A tracheostomy was performed, and a cuffless endotracheal tube was fitted, secured with a proximal suture to prevent leakage. The rabbits were ventilated with room air at a respiratory rate appropriate to maintain normal end-tidal capnography with a positive-end expiratory pressure (PEEP) of $2 \mathrm{~cm} \mathrm{H} \mathrm{H}_{2} \mathrm{O}$. The positive inspiratory pressure (PIP) was maintained between 20 and $30 \mathrm{~cm} \mathrm{H}_{2} \mathrm{O}$ per auscultation, the $\mathrm{pH}$ was kept over 7.40, and the $\mathrm{PCO}_{2}$ less than $40 \mathrm{~mm} \mathrm{Hg}$, to ensure the absence of spontaneous ventilatory efforts. The left carotid artery was cannulated to provide a site for sampling blood and blood pressure measurements. The left and the right internal jugular veins were surgically isolated and served as the cannulation sites for venovenous bypass.

\section{Extracorporeal circuit}

The bypass circuit consisted of $1 \mathrm{~m}$ of onequarter-inch by one-sixteenth-inch flexible polyvinylchloride (PVC) tubing, argyle PVC catheters (No, 8) for vascular access, and three-sixteenth-inch by one-quarter-inch rigid PVC connectors. In some of the study groups, tubing, catheters, and connectors were heparin coated (Carmeda, Medtronic Blood Systems, Anaheim, CA, U.S.A.). The circuit was primed with Ringer's lactate and inserted in a roller pump with occlusion settings according to the clinical protocol of neonatal extracorporeal life support. The jugular veins were cannulated and connected to the tubing. The total circuit volume was approximately $30 \mathrm{ml}$. Bypass was maintained at a flow rate of approximately $60-80 \mathrm{ml} / \mathrm{min}$ (or 20 $\mathrm{ml} / \mathrm{kg}$ ) for $2 \mathrm{~h}$. Thereafter, the animal was sacrificed with an overdose of xylazine followed by potassium chloride. Death was verified by cardiac monitoring.

\section{Experimental groups}

Four experimental groups were studied: Group A $(\mathbf{n}=5)$ being an uncoated circuit and systemic heparinization, Group B $(\mathrm{n}=5)$ being an uncoated circuit without systemic heparinization, Group $\mathrm{C}$ $(\mathrm{n}=5)$ a heparin-coated circuit plus systemic hepa- rinization, and Group D $(\mathrm{n}=5)$ a heparin-coated circuit but without systemic heparinization. Animals with baseline hematologic abnormalities or those that developed technical complications were excluded from this study.

\section{Blood collection}

Blood samples were drawn immediately after the insertion of the arterial catheter (baseline) and 10 , 30,60 , and $120 \mathrm{~min}$ after the onset of bypass. The amount of blood drawn at each time point was $3 \mathrm{ml}$. One milliliter of blood, anticoagulated with ethylenediaminetetraacetic acid (EDTA, 0.01M), was collected for blood cell counts. Two milliliters of blood was anticoagulated with $0.3 \%$ sodium citrate and centrifuged, and the plasma was stored at $-80^{\circ} \mathrm{C}$ for complement $\left(\mathrm{CH}_{50}\right)$ assays and for determination of $\beta$-glucuronidase and tumor necrosis factor (TNF).

\section{Assays \\ Leukocyte numbers were counted with a cell counter (Counter Electronics, Inc., Hialeah, FL, U.S.A.). Hemoglobin was measured using a IL 482 co-oximeter (Instrumentation Laboratories, Lexing- ton, MA, U.S.A.). The complement hemolytic assay $\left(\mathrm{CH}_{50}\right)$ was performed according to Mayer (15) with sheep red blood cells incubated with $1: 2$ to $1: 32$ stepwise diluted rabbit serum. The $\beta$-glucuronidase plasma concentration was measured according to Baehner (16). A mixture of $1 \mathrm{ml}$ substrate $p$-ni- trophenyl $\beta$-D-glucopyranosid uric acid solution (Merck, Darmstadt, Germany) and $50 \mu \mathrm{l}$ rabbit plasma was incubated for $2 \mathrm{~h}$ at room temperature. The conversion of the substrate by plasma $\beta$-gluc- uronidase was determined in a spectrophotometer at $410 \mathrm{~nm}$. TNF activity in the plasma was measured using a sensitive bioassay with the WEHI 164 sub- clone 13 cell line as previously described (17).}

\section{Statistics}

The data of leukocyte numbers, $\mathrm{CH}_{50}, \beta$-glucuronidase, and TNF concentrations were corrected for dilution and are presented as means \pm standard deviation (SD) for each group. One-way analysis of variance (ANOVA) was used to assess differences of means between groups. A p value of less than 0.05 was considered to be significant.

\section{RESULTS}

\section{Complement consumption $\left(\mathrm{CH}_{50}\right)$}

In the uncoated group the $\mathrm{CH}_{50}$ remained unchanged throughout the entire period of extracorpo- 


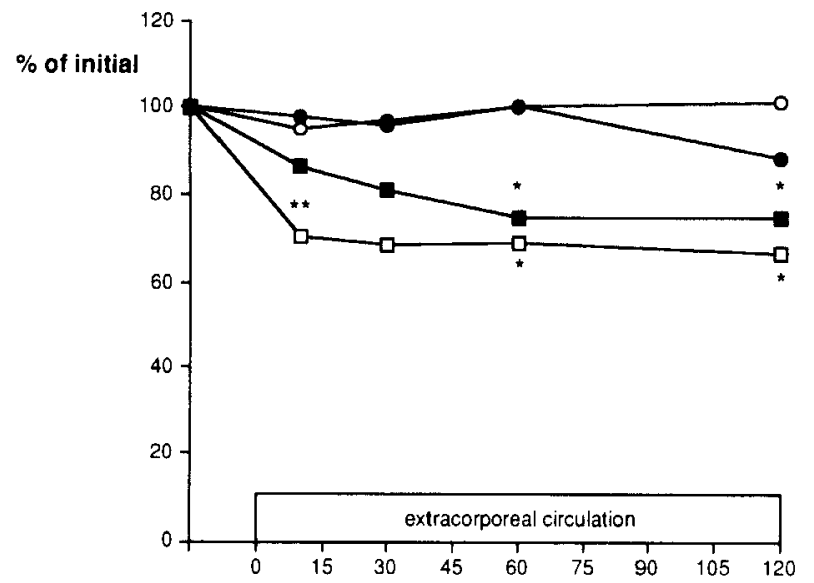

FIG. 1. Complement hemolytic activity $\left(\mathrm{CH}_{50}\right)$ expressed as mean percentage of initial value in the control group (open circle), in the uncoated without systemic heparin group (closed circle), in the heparin-coated group with systemic heparin (open square), and in that without systemic heparin (closed square). " $p<0.05$ vs. Group A; ${ }^{* *} p<0.05$ vs. Group $A$ and vs. Group B.

real circulation (Fig. 1). In the heparin-coated groups, however, the $\mathrm{CH}_{50}$ decreased immediately after start of bypass, and a level of about $70 \%$ of baseline was reached after $1 \mathrm{~h}(\mathrm{p}<0.05)$. This level was maintained during the rest of the bypass.

\section{Leukocyte numbers}

The leukocyte numbers dropped immediately after the start of extracorporeal circulation in all groups (Fig. 2). Minimum levels were reached 30

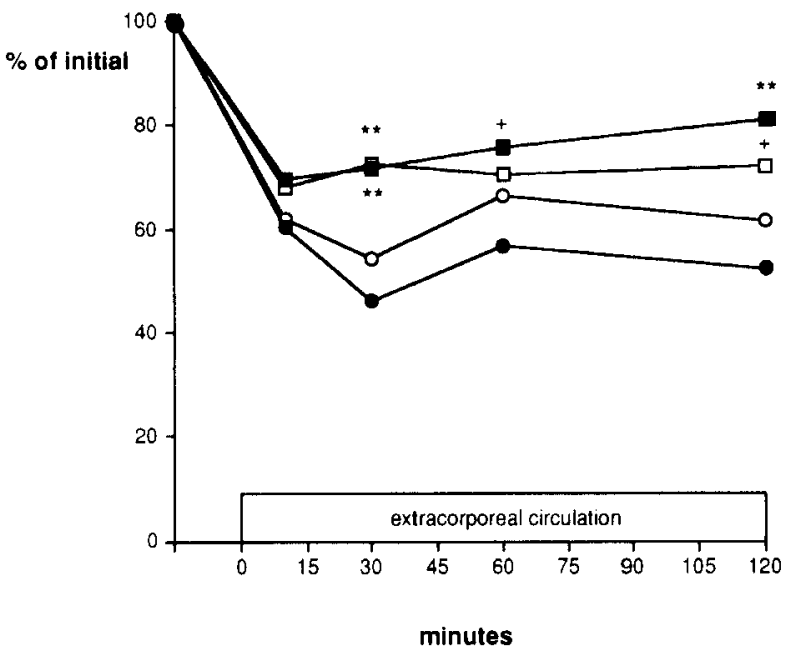

FIG. 2. Leukocyte numbers expressed as mean percentage of initial value in the control group (open circle), in the uncoated without systemic heparin group (closed circle), in the heparincoated group with systemic heparin (open square), and in that without systemic heparin (closed square). ${ }^{*} p<0.05$ vs. Group A and vs. Group B; ${ }^{+} p<0.05$ vs. Group B.

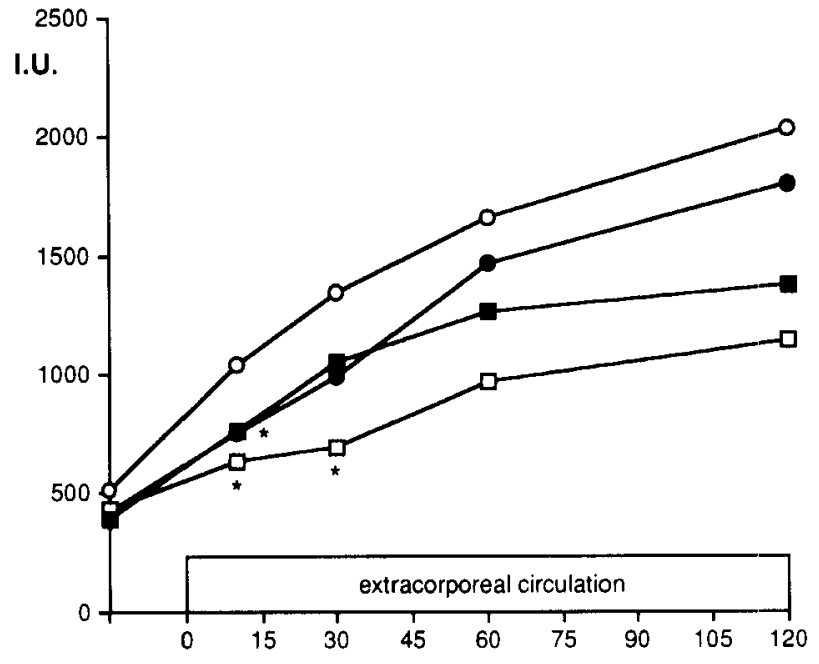

FIG. 3. $\beta$-Glucuronidase concentrations expressed as means in the control group (open circle), in the uncoated without systemic heparin group (closed circle), in the heparin-coated group with systemic heparin (open square), and in that without systemic heparin (closed square). ${ }^{*} p<0.05$ vs. Group $A$

min after the start of bypass and were respectively $50 \%$ of initial value in the noncoated groups and $70 \%$ in the heparin-coated groups. The leukocyte numbers remained significantly higher in the heparin-coated groups throughout the entire period of bypass than in the noncoated groups $(\mathrm{p}<0.05)$. Leukopenia was still present in all groups after $2 \mathrm{~h}$ of extracorporeal circulation.

\section{$\boldsymbol{\beta}$-Glucuronidase}

The granulocytic release product $\beta$-glucuronidase increased rapidly upon start of bypass in all groups but was significantly lower in the heparin-coated groups ( $p<0.05$ ) (Fig. 3). After $2 \mathrm{~h}$ of bypass, the $\beta$-glucuronidase concentrations increased in the uncoated groups with systemic heparin to $2,029 \pm 902$ IU and without systemic heparin to $1,796 \pm 1,043$ IU. At that time point, the $\beta$-glucuronidase concentrations increased in the heparin-coated groups with systemic heparin to $1,140 \pm 420 \mathrm{IU}$ and without systemic heparin to $1,380 \pm 656 \mathrm{IU}$. These increases and differences between the groups correlated inversely with the decrease in leukocyte numbers.

\section{Tumor necrosis factor}

TNF concentrations increased rapidly upon start of bypass in the uncoated groups to about $300 \%$ of initial value after $30 \mathrm{~min}$ of bypass (Fig. 4). In the heparin-coated group, no increase in TNF was measured throughout the entire period of bypass, thus TNF was significantly lower in the heparin-coated groups ( $p<0.05$ ). After $2 \mathrm{~h}$ of extracorporeal circu- 


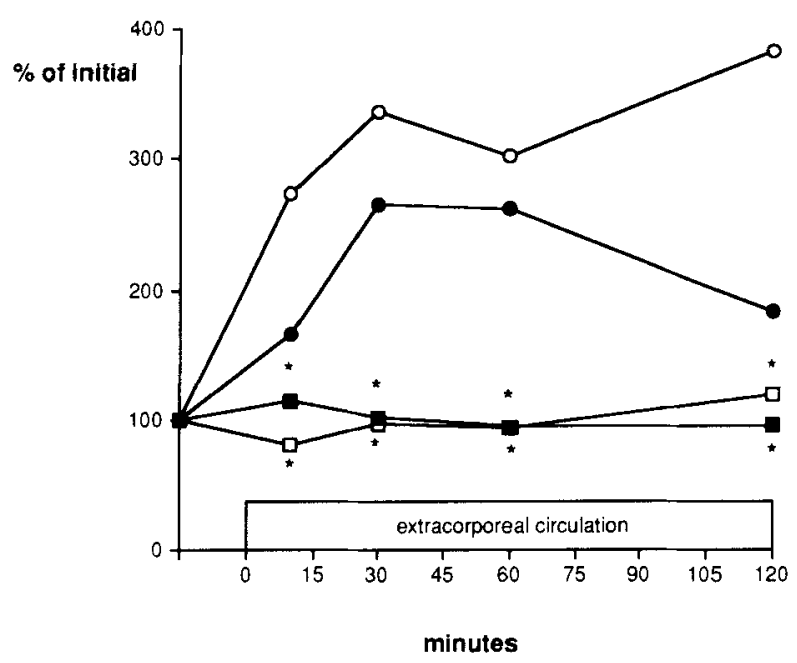

FIG. 4. TNF concentrations expressed as mean percentage of initial value in the control group (open circle), in the uncoated without systemic heparin group (closed circle), in the heparincoated group with systemic heparin (open square), and in that without systemic heparin (closed square). " $p<0.05$ vs. Group A.

lation, TNF was still elevated in the uncoated groups.

\section{DISCUSSION}

Complement activation during extracorporeal circulation is modified by coating the blood-contact surfaces with endpoint-attached, functionally active heparin. This is substantiated by the significantly reduced $\mathrm{CH}_{50}$ activity, the remaining higher leukocyte numbers, the significantly decreased release of $\beta$-glucuronidase, and most strikingly the complete prevention of TNF formation in the heparin-coated group.

The significantly reduced $\mathrm{CH}_{50}$ activity in the heparin-coated groups indicates the inhibitory action of heparin coating on complement activation. The $\mathrm{CH}_{50}$ assay represents the ability of plasma to generate the terminal complement complex through the classical pathway, which has cell-membrane-attacking capacity. Red blood cells (RBC) present in the assay are targets for the activated complement proteins and will be lysed in the assay only if all the complement proteins are present in adequate levels and are functional. The complement protein present in the lowest concentration (i.e., the minimum concentration required for further activation) is the limiting factor in the amount of lysis a test serum will produce.

The significantly reduced $\mathrm{CH}_{50}$ activity in the plasma samples obtained from the heparin-coated groups indicates the reduction of one or more native classical complement products. This reduction may be due to high activation and subsequent consumption during extracorporeal circulation of rabbit blood. Alternatively, the reduction may be due to loss of complement components during extracorporeal circulation without activation. An enhanced activation process by heparin coating is not likely since heparin has been shown to inhibit C3-convertase $(9-11)$. Thus, heparin coating may promote the binding of certain complement factors to the surface of the heparin-coated extracorporeal circuit and subsequently cause depletion of these factors in the fluid phase. The complement cascade will then exert reduced activity ex vivo. The hypothesis that complement factors bind to the heparin-coated surface may also explain the difference between the effects of systemic heparin and heparin coating even when the affinities between complement factors and heparin are similar. Once bound to systemic heparin, the complement factors remain in circulation and obviously can still be recruited to allow the cascade to function normally. However, we realize that the support for our hypothesis is not complete. We were unable to measure in this rabbit model the absorption of complement components to the surface or to measure quantitative levels of individual components in plasma; therefore, it is necessary to perform further studies to elucidate which complement components are truly absorbed.

Although we were unable to measure quantitative levels of complement products in our in vivo rabbit model, it is likely that only small amounts of the bioactive complement products $\mathrm{C} 5 \mathrm{a}$ and $\mathrm{C} 5 \mathrm{~b}-9$ were formed in the heparin-coated groups. This assumption is supported both by ex vivo studies with human blood and by in vivo studies in which no or only small amounts of C5a were formed in heparin-coated circuits $(13,14)$. Furthermore, C5a stimulates monocytes to release TNF (18), which was completely prevented in the heparin-coated groups. However, the possibility may exist that TNF is produced as well in the heparin-coated groups but that TNF is also absorbed by the circuit.

The inhibitory effect of heparin coating on C5a generation is also in accordance with the positive effect on leukocyte numbers and the lower concentrations of $\beta$-glucuronidase. C5a stimulates leukocytes to adhere, to aggregate on endothelial cells, to migrate extravascularly, and to release their enzymes (19-21). Aggregation of polymorphonuclear leukocytes (PMN) results in leukopenia and their pulmonary sequestration $(22,23)$. The activation of leukocytes is reflected by the elevated concentrations of release products, such as elastase or $\beta$-gluc- 
uronidase $(24,25)$. These inflammatory mediators are considered to be responsible for the whole-body inflammatory reaction in CPB, causing organ dysfunction (1-6); thus heparin coating may be of great clinical importance in reducing this reaction during extracorporeal life support.

In conclusion, this study showed that heparin coating improved the biocompatibility of extracorporeal circuits by modifying complement activation in such a way that it reduced the release of leukocyte inflammatory mediators during extracorporeal circulation.

Acknowledgments: We would like to thank the Medtronics Corporation for supplying the Carmeda-coated circuits for evaluation, Daniel Remick, M.D., for TNF evaluation, and J. Haan and F. Wei for their excellent technical assistance. This research was supported by a grant of the J.K. de Cock Stichting to Frans Plötz.

\section{REFERENCES}

1. Chenoweth DE, Cooper SW, Hugli TE, Stewart RW, Blackstone EH. Kirklin JW. Complement activation during cardiopulmonary bypass: evidence for generation of $\mathrm{C} 3 \mathrm{a}$ and $\mathrm{C} 5 \mathrm{a}$ anaphylatoxins. N Engl J Med 1981;304:497-503.

2. Kirklin JK, Westaby S, Blackstone EH, Kirklin JW, Chenoweth DE, Pacifico AD. Complement and the damaging effect of cardiopulmonary bypass. I Thorac Cardiovasc Sarg $1983 ; 86: 845-57$

3. Van Oeveren $W$, Kazatchkine MD, Descamps-Latscha B, Maillet F, Fischer E, Carpentier A. Wildevuur CRH. Deleterious effects of cardiopulmonary bypass. A prospective study of bubble versus membrane oxygenation. $J$ Thorac Cardiovase Surg 1985;89:888-99.

4. Van Oeveren W, Wildevuur CRH. Blood compatibility of cardiopulmonary bypass circuits: review. Perfusion $1987 ; 2: 237-44$.

5. Westaby S. Organ dysfunction of cardiopulmonary bypass. A systemic inflammation reaction initiated by the extracorporeal circuit. Intensive Care Med 1987;13:89-95.

6. Van Oeveren W, Wildevuur CRH, Kazatchkine MD. Biocompatibility of extracorporeal circuits in heart surgery. Trans Sci 1990;11:5-33.

7. Salama A. Hugo F, Heinrich D. Hoge R, Muller R, Kiefel V, Mueller-Eckhardt C, Bhakdi S. Deposition of terminal C5b-9 complement complexes on erythrocytes and leukocytes during cardiopulmonary bypass. $N$ Engl $J$ Med 1988;73:40814.

8. Heideman M. Norder-Hansson B, Bengston A, Mollnes TE. Terminal complement complexes and anaphylatoxins in septic and ischemic patients. Arch Surg 1988:123:188-92.
9. Weiler JM, Yurt RW, Fearon DT, Austen KF. Modulation of the formation of the amplification convertase of complement $\mathrm{C} 3 \mathrm{bBb}$, by native and commercial heparin. $J$ Exp Med 1978;147:409-21.

10. Kazatchkine MD, Fearon DT, Metcalfe DD, Rosenberg RD, Austen KF. Structural determinants of the capacity of heparin to inhibit the formation of the human amplification convertase. J Clin Invest 1981;67:223-8.

11. Wegmüller E. Kazatchkine MD, Nydegger UE. Complement activation during extracorporeal blood bypass. Plasma Ther Transfus Technol 1983;4:361-71.

12. Nilsson L, Storm KE, Thelin S, Bagge L, Hultman J. Thorelius J, Nilsson U. Heparin-coated equipment reduces complement activation during cardiopulmonary bypass in the pig. Artif Organs 1990:14:46-8.

13. Mollnes TE, Videm V, Götze O, Harboe M. Opperman M. Formation of C5a during cardiopulmonary bypass: inhibition by precoating with heparin. Ann Thorac Surg 1991;52:92-7.

14. Videm V, Mollness TE, Garred P, Svennevig JL. Biocompatibility of extracorporeal circulation: in vitro comparison of heparin-coated and uncoated oxygenator circuits. I Thorac Cardiovasc Sirrg 1991;101:654-60.

15. Mayer MM. Complement and complement fixation. In: Kabat EA, ed. Experimental immunochemistry. Springfield, Illinois: Charles C Thomas, 1971:133-40.

16. Batehner RL. Subcellular distribution of nitroblue tetrazollium reductase (NBT-R) in human polymorphonuclear leucocytes (PMN). J Lab Clin Med 1975;806:785-92.

17. Eskandari MK, Nguyen DT, Kunkel SL, Remick DG. WEHI 164 subclone 13 assay for TNF: sensitivity, specificity, and reliability. Immunol Invest 1990:19:69-79.

18. Rock CS, Lowry SF. Current research review. Tumor necrosis factor-alpha. J Surg Res 1991;51:434-45.

19. Williams JJ, Yellin SA. Slotman GJ. Leukocyte aggregation response to quantitative plasma levels of $\mathrm{C} 3 \mathrm{a}$ and $\mathrm{C} 5 \mathrm{a}$. Arch Surg 1986:121:305-7.

20. Tonnesen MG. Smedly LA. Henson PM. Neutrophil-endothelial cell interactions. Modulations of neutrophil adhesive. ness induced by complement fragments C5a and C5a des Arg and formyl-methionyl-leucyl-phenylalanine in vitro. $J$ Clin Invest 1984;74:1581-92.

21. Henson PM, Zanolari B, Schwartzman NA, Hong SR. Intracellular control of human neutrophil secretion. I. C5a-induced stimulus-specific desensitization and the effects of cytochalasin B. J Immunol 1978:121:851-5.

22. Craddock PR, Fehr J, Dalmasso AP, Brigham KL, Jacob HS. Hemodialysis leukopenia. Pulmonary vascular leukostasis resulting from complement activation by dialyser cellophane membranes. J Clin Invest 1977;59:879-88.

23. Craddock PR, Fehr J, Brigham KL, Kronenberg RS, Jacob HS. Complement and leukocyte mediated pulmonary dysfunction in hemodialysis. $N$ Engl J Med 1977;296:769-74.

24. Sibille Y, Reynolds HY. Macrophages and polymorphonuclear neutrophils in lung defense and injury. Am Rev Respir Dis 1990;141:471-501.

25. Schraufstatter J, Revak S, Cochrane CG. Proteases and oxidants in experimental pulmonary inflammatory injury. $J$ Clin Invest $1984 ; 73: 1175-84$. 